\title{
FSH, Oxytocin and IGF-I Regulate the Expression of Sirtuin 1 in Porcine Ovarian Granulosa Cells
}

\author{
Alexander V. SIROTKIN ${ }^{1,2}$, Petra DEKANOVÁ ${ }^{1}$, Abdel Halim HARRATH ${ }^{3}$ \\ ${ }^{1}$ Department of Zoology and Anthropology, Faculty of Sciences, Constantine The Philosopher \\ University in Nitra, Nitra, Slovak Republic, ${ }^{2}$ Research Institute of Animal Production, Lužianky, \\ Slovak Republic, ${ }^{3}$ College of Science, King Saud University, Riyadh, Saudi Arabia
}

Received December 20, 2019

Accepted February 12, 2020

Epub Ahead of Print May 29, 2020

\section{Summary}

The involvement of the mTOR system/enzyme sirtuin 1 (SIRT1) intracellular signaling system in the control of ovarian functions and its role in mediating hormonal action on the ovary has been proposed, but this hypothesis should be supported by a demonstrated influence of hormones on mTOR/SIRT1. Therefore, the aim of our in vitro experiments was to examine the effect of the known hormonal regulators of ovarian functions, such as follicle-stimulating hormone (FSH), oxytocin (OT) and insulin-like growth factor I (IGF-I), on mTOR/SIRT1. The accumulation of SIRT1 in porcine ovarian granulosa cells cultured with and without these hormones (at doses of 1,10 or $100 \mathrm{ng}^{\mathrm{ml}}{ }^{-1}$ ) was evaluated using immunocytochemistry. It was observed that the addition of FSH (at $10 \mathrm{ng}^{-1} \mathrm{~m}^{-1}$ but not at 1 or $100 \mathrm{ng} / \mathrm{ml}$ ) and OT (at all tested doses) increased the expression of SIRT1 in ovarian cells. In addition, $100 \mathrm{ng}^{\mathrm{ml}} \mathrm{l}^{-1}$, but not at 1 or $10 \mathrm{ng}^{-1} \mathrm{ml}^{-1}$, of IGF-I decreased SIRT1 accumulation. Our observations are the first demonstration that hormones can directly regulate the ovarian mTOR/SIRT1 system and that this system could mediate the action of hormonal regulators on the ovary.

\section{Key words}

Pig • Ovarian granulosa cells • Sirtuin $1 \bullet \mathrm{FSH} \bullet$ Oxytocin $\bullet$ IGF-I

\section{Corresponding author}

A. V. Sirotkin, Department of Zoology and Anthropology, Faculty of Natural Science, Constantine The Philosopher University in Nitra, Tr. A. Hlinku 1, 94974 Nitra, Slovak Republic. E-mail: asirotkin@ukf.sk

\section{Introduction}

Studies of both extra- and intracellular regulators of reproduction as well as their interrelationships are important from both theoretical and practical viewpoints. The mTOR signaling system and its key enzyme, sirtuin 1 (SIRT1), have been extensively studied in recent years. SIRT1 is a member of the $\mathrm{NAD}^{+}$-dependent deacetylase family (Frye 2000, Jin et al. 2009). It is widely expressed in numerous cell types, including ovarian cells. In nonovarian cells, SIRT1 regulates metabolism, hormone secretion, cell cycle and cell differentiation and is protective against cellular oxidative stress, DNA damage, apoptosis, aging and inflammation (Bordone et al. 2006, $\mathrm{Fu}$ et al. 2006, Haigis and Guarente 2006, Wolf 2006, Rajendrasozhan et al. 2008, Rodgers et al. 2008). It is known that food restriction regulates both reproduction and SIRT1 activity and that food restriction can potentially control reproduction through SIRT1 (Wolf 2006). SIRT1 is involved in control of various reproductive processes including basic ovarian functions (see Tatone et al. 2015 for review). SIRT1 directly stimulates spermatogenesis but not oogenesis (Coussens et al. 2008) and reduces ovarian cell viability and promotes ovarian progesterone release (Morita et al. 2012) in rodents. SIRT-1 overexpression was associated with promotion of mice ovarian follicullogenesis and fecundity (Long et al. 2019), whilst its knock-down has an opposite effect (Tatone et al. 2018). SIRT1 might control reproductive processes through the induction of GnRH expression, LH release (KolthurSeetharan 2009) and the induction of LH receptors (Morita

PHYSIOLOGICAL RESEARCH • ISSN 1802-9973 (online) 
et al. 2012). The transfection-induced overexpression of SIRT1 in cultured porcine ovarian granulosa cells reduced their proliferation, increased progesterone and insulin-like growth factor I (IGF-I) release and modified the response of granulosa cells to exogenous follicle-stimulating hormone (FSH; Pavlová et al. 2013, Sirotkin et al. 2014, Sirotkin 2016).

FSH and other hormones as well as growth factors including oxytocin (OT) and IGF-I are the most well known regulators of ovarian functions. Their effect on ovarian cells could be mediated via various intracellular signaling molecules (Sirotkin 2014). However, there is insufficient evidence for the role of mTOR/SIRT1 in mediating hormone action on ovarian cells. Such direct evidence could include (1) changes in the expression of SIRT1 under the influence of this hormone, (2) the ability of SIRT1 to affect ovarian functions controlled by this hormone and (3) the ability of SIRT1 to modify the action of this hormone on ovarian cells. Previously, we reported on the ability of SIRT1 to affect porcine ovarian cell functions and to modify FSH action on these cells (see above). Ovarian stimulation by gonadotropins has been associated with increased SIRT-1 level in serum, but not in ovarian follicular fluid (Bódis et al. 2018); however, the effect of hormonal regulators on ovarian SIRT1 has not yet been examined.

The aim of our in vitro experiments was to examine the effect of the addition of known hormonal regulators of ovarian functions, FSH, OT and IGF-I at various doses on SIRT1 accumulation in cultured porcine ovarian granulosa cells.

\section{Materials and Methods}

\section{Preparation, culture and processing of ovarian cells}

The major experimental protocols, including cell culture and their validation have been described in our previous publications (Meszarosova et al. 2008, Pavlova et al. 2011, Pavlova et al. 2013, Sirotkin et al. 2014). Briefly, primary granulosa cells were aspirated from the ovaries of prepubertal gilts that were 100-120 days of age at a local abattoir; the cells were resuspended in Dulbecco's modified Eagle's medium (DMEM)/F-12 1:1 $+10 \%$ fetal calf serum and $1 \%$ antibiotic-antimycotic solution (all of which were purchased from Sigma, St. Louis, MO, USA), dispensed to 16-well chamber slides (Nunc International, Naperville, TN, USA) in $200-\mu \mathrm{l}$ aliquots and incubated at $37.5^{\circ} \mathrm{C}$ and $5 \% \mathrm{CO}_{2}$ humidified air until the formation of a 50-60\% confluent monolayer (48-72 h). After primary culture, the media from the plates were aspirated, and the cells were washed with fresh DMEM/F12. Then, the cells were cultured for two days with and without porcine FSH (Dr. A.P.F. Parlow, NHPP, Torrance, CA, USA), oxytocin (Sigma) or IGF-I (Sigma) added to the culture medium at concentrations of $0,1,10$ or $100 \mathrm{ng}^{\mathrm{ml}} \mathrm{m}^{-1}$. At the end of the culture, cell numbers and viability were determined by Trypan blue staining and cell counting with a hemocytometer. Cell viability was $70-80 \%$. No statistically significant differences in these indices were observed between the control and experimental groups.

After removing the medium from the chamber slides, cells were washed in ice-cold PBS ( $\mathrm{pH} 7.5$ ), fixed in paraformaldehyde (4\% in PBS, $\mathrm{pH} 7.2-7.4$ ), dehydra-ted in a graded alcohol series $(70 \%, 80 \%, 96 \% ; 10$ min each) and stored at $4{ }^{\circ} \mathrm{C}$ until the immunocytochemical analysis.

\section{Immunocytochemical analysis}

The immunocytochemical analysis method was previously validated for porcine granulosa cells (Meszarosova et al. 2008, Pavlova et al. 2011, Pavlova et al. 2013, Sirotkin et al. 2014). The presence of SIRT1 was detected using immunocytochemistry (Osborn and Isenberg 1994). This method quantitative immunocytochemistry for SIRT-1 detection, quantification and changes in its accumulation in porcine granulosa cells has been previously validated by Western immunoblotting and other methods (Pavlova et al. 2013, Sirotkin et al. 2014, Sirotkin 2016). Primary mouse monoclonal antibodies against SIRT1 (Santa Cruz Biotechnology, Inc., Santa Cruz, CA, USA, catalogue number B-7, initial concentration $200 \mu \mathrm{g} . \mathrm{ml}^{-1}$ ) were used at a dilution of $1: 250$. The visualization of the binding of primary antibodies was achieved with secondary polyclonal goat antibodies against mouse IgGs. The secondary antibodies labeled with the fluorescent marker fluorescein isothiocyanate (FITC) provided in a concentration $200 \mu \mathrm{g} \cdot \mathrm{ml}^{-1}$ by Santa Cruz Biotechnology, applied at a dilution of 1:1000 and mounted in a Vectashield with DAPI (Vector Laboratories, Inc., Burlingame, CA, USA). The presence of SIRT1 was determined by fluorescent microscopy by using Leica Microsystems (Wetzlar, Germany). The cells expressing signal above background negative control levels were considered positive. The percentage of cells containing visible antigen was counted. Cells processed without the primary antibody were used as the negative control. Images of stained cells and negative control are shown in Fig. 1. 


\section{Statistics}

Each experimental group was represented by three chamber-slide wells. The data shown are the means of the values obtained in these three separate experiments performed on separate days with separate groups of granulosa cells, each obtained from 15-20 animals. At least 10 optical fields were analysed in each chamber. In each chamber (three per group), at least 1000 cells were scored. Each value represents the mean of nine replicates (at least 9000 cells in total). The percentage of cells containing antigen in different groups of cells was calculated. Significant differences between the experiments were evaluated with two-way ANOVA followed by chi-square test using SigmaPlot 11.0 software (Systat Software, $\mathrm{GmbH}$, Erkhart, Germany). Differences from control at $\mathrm{P}<0.05$ were considered significant.

\section{Results and Discussion}

Immunocytochemical analysis showed the presence of SIRT1 in porcine ovarian granulose cells after culture. SIRT1 was presented in the cells as cytoplasmic clusters (Fig. 1). The percentage of cells containing SIRT1 varied between 3 and $75 \%$, and this percentage was affected by hormonal treatments (Fig. 2). The addition of FSH at a dose of $10 \mathrm{ng} \cdot \mathrm{ml}^{-1}$ but not at lower $(1 \mathrm{ng} / \mathrm{ml})$ or higher $\left(100 \mathrm{ng} \cdot \mathrm{ml}^{-1}\right)$ increased the expression of SIRT1 in the cells (Fig. 2A). OT increased the expression of SIRT1 in ovarian cells at all doses added (1, 10 or 100 ng. $\mathrm{ml}^{-1}$ ) (Fig. 2B). IGF-I decreased SIRT1 accumulation when added at the highest (100 ng. $\mathrm{ml}^{-1}$ ) but not at lower (1 or $10 \mathrm{ng} \cdot \mathrm{ml}^{-1}$ ) doses (Fig. 2C).

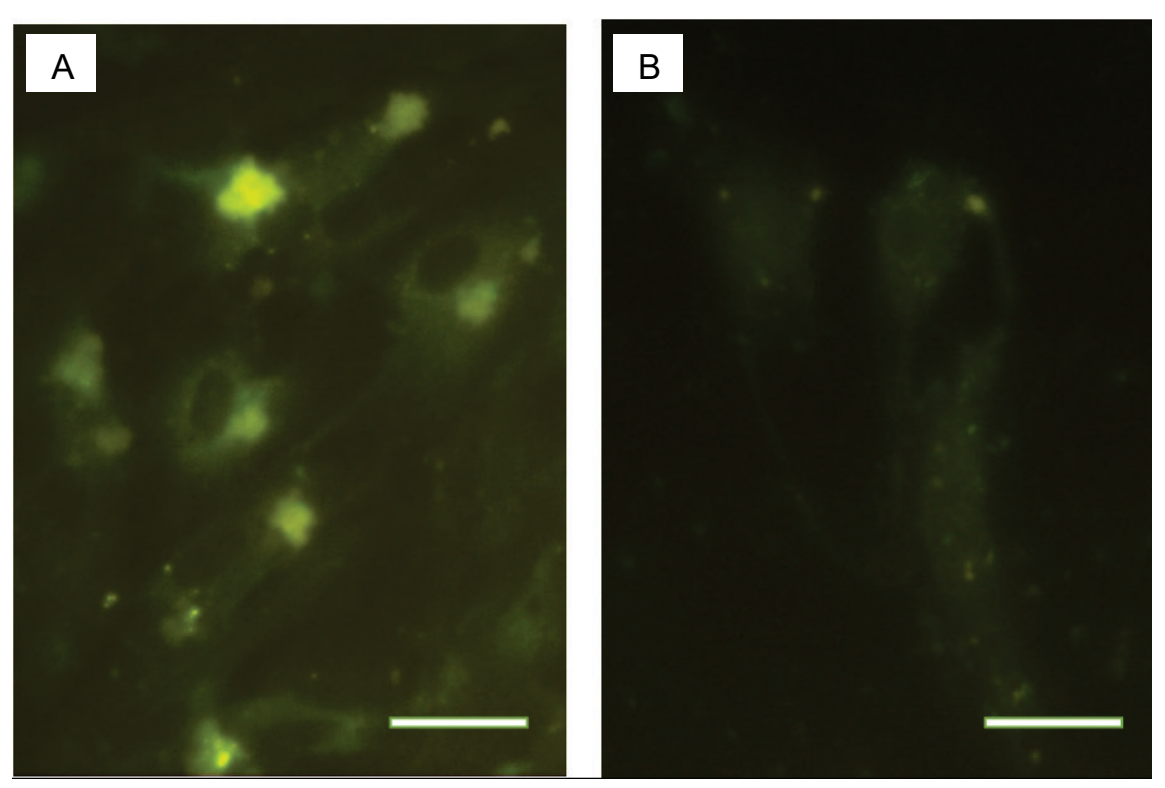

Fig. 1. Immunocytochemistry images showing cultured porcine granulosa cells containing sirtuin 1 (Leica Microsystems, Wetzlar, Germany). (A) specific staining by using primary antiserum against sirtuin 1 and secondary antiserum labelled with fluorescein isothiocyanate (FITC; green fluorescence). (B) negative control (staining with secondary antibody with FITC without primary antibody). Scale bars: $1 \mathrm{~cm}=20 \mu \mathrm{m}$.

Our observations confirm our previous data (Pavlova et al. 2013, Sirotkin et al. 2014) on the presence of SIRT1 in cultured porcine ovarian granulosa cells. Furthermore, they are the first evidence that the expression of SIRT1 in ovarian cells might be controlled by FSH, OT and IGF-I. These hormones are well-known regulators of various ovarian functions, including cell proliferation, apoptosis, release of steroid and peptide hormones, ovarian folliculogenesis and follicle selection, oogenesis, ovulation and luteogenesis. The intracellular mechanisms and mediators of hormone action on these processes are not completely elucidated, but the involvement of receptors, protein kinases, transcription factors and small RNA has been documented (see
Sirotkin 2014 for review). It remains unknown whether the effects of hormonal regulators of ovarian functions could be mediated by SIRT1. We propose, that the hypothetical mediator of hormone action (1) changes under the influence of this hormone, (2) affects ovarian functions controlled by this hormone and (3) when changed, modifies the hormone effects. Our previous experiments with transfection of porcine ovarian granulose cells with a cDNA construct for SIRT1 (Pavlová et al. 2013, Sirotkin et al. 2014) and other studies of SIRT1 regulators effects (Sirotkin 2016, Tatone et al. 2018) demonstrated the involvement of SIRT in both basic ovarian functions (proliferation, apoptosis, secretory activity and expression of 

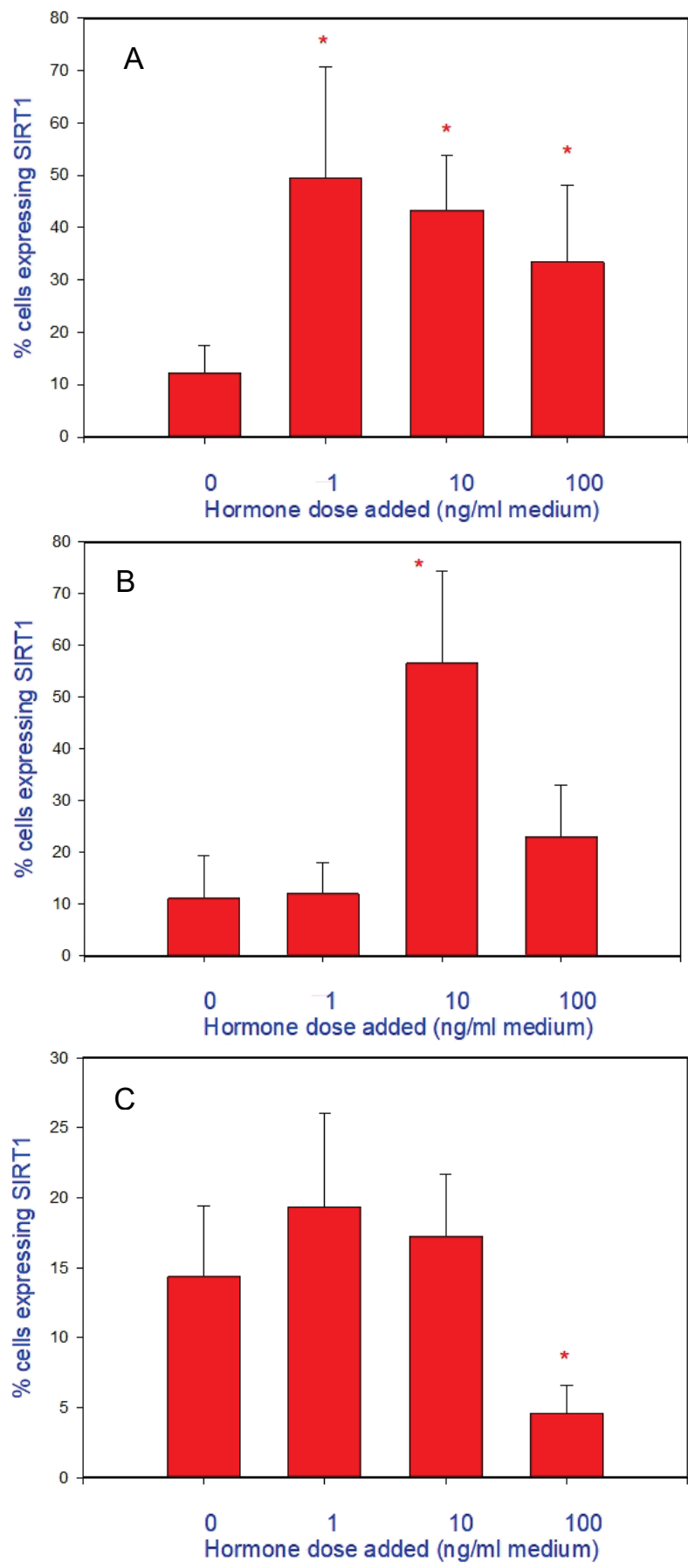

Fig. 2. Effect of FSH (A), OT (B) and IGF-I (C) on the percentage of porcine granulosa cells expressing SIRT1. Monolayers of granulosa cells from prepubertal gilts were cultured with or without FSH, OT or IGF-I $\left(0,1,10,100 \mathrm{ng}^{\mathrm{ml}} \mathrm{l}^{-1}\right.$ medium). After two days of culture, the cells were analyzed by immunocytochemistry. Data are the mean \pm S.D. * - Effect of hormone addition: significant $(P<0.05)$ differences between the cells cultured with $(1,10$ or $100 \mathrm{ng} / \mathrm{ml})$ and without $(0 \mathrm{ng} / \mathrm{ml})$ hormone.

transcription factors) and modifications of the effect of FSH on transcription factor NF- $\kappa \mathrm{B}$. Curcumin-induced activation of SIRT1 gene was associated with reduction in plasma FSH level and activation of murine reproductive processes (Azami et al. 2020), as well as with changes in rabbit ovarian hormones release and fecundity (Sirotkin et al. 2018). Curcumin changed also response of rabbit ovarian cells to $\mathrm{LH}$ (Sirotkin et al. 2018). Furthermore, resveratrol-induced stimulation of SIRT1 accumulation was associated with changes in character of IGF-I action on apoptosis and testosterone release by porcine granulosa cells (Sirotkin et al. 2019a). Food restriction affecting mTOR/SIRT1 was able to modify also ghrelin action on chicken (Sirotkin et al. 2017b) and rabbit (Sirotkin et al. 2017a) hormones and reproduction in vivo and on response of rabbit ovarian cells to IGF-I (Sirotkin et al. 2017a). The present observations related to the action of FSH, OT and IGF-I on the expression of SIRT in porcine ovarian cells represent the first demonstration of direct regulation of ovarian SIRT-1 by hormones and indication that SIRT1 may be involved in mediating the effect of these hormones on the ovary. Moreover, the differences in character of hormones action on SIRT-1 indicate, that FSH, OT and IGF-I can affect SIRT1 via different signaling pathways documented previously (Sirotkin 2014). Alternatively, these hormones can affect not only SIRT-1, but also other signaling molecules (Sirotkin 2014) whose in turn could affect SIRT-1 directly or via feedback mechanisms. On the contrary, mTOR/SIRT1 system can modify FSH release (Tatone et al. 2015, Azami et al. 2019), as well as FSH (Morita et al. 2012, Sirotkin et al. 2019b), LH (Sirotkin et al. 2018) and IGF-I (Sirotkin et al. 2019a) action. Taken together, these observations demonstrate the involvement of mTOR/SIRT1 system in endocrine control of ovarian functions.

\section{Conclusions}

The hypothesis concerning the role of SIRT1 as a mediator of hormone action on ovarian cells requires further confirmation. Moreover, the involvement of SIRT1 in the control of particular ovarian functions and the ability of SIRT1 to modify the action of various hormones on these functions should be supported by more data. Nevertheless, our present preliminary study is the first to provide evidence that hormones can direct regulate ovarian SIRT-1, and that some effect of hormonal regulators on the ovary may be mediated by the mTOR/SIRT1 intracellular signaling system. 


\section{Conflict of Interest}

There is no conflict of interest.

\section{Acknowledgements}

The authors express their gratitude to Ing. Ž. Kuklová and Ms. K. Tóthová for skillful help in processing the samples. These studies were supported by the Slovak
Research and Development Agency (APVV) under the contract number APVV-15-0296, the Slovak Grant Agency of the Ministry of Education, Science and Sport, the Slovak Academy of Science (VEGA) projects (VEGA 1/0327/16), and Researchers Supporting Project number RSP-2020/17, King Saud University, Riyadh, Saudi Arabia.

\section{References}

AZAMI SH, NAZARIAN H, ABDOLLAHAFIR MA, EINI F, FARSANI MA, NOVIN MG: The antioxidant curcumin postpones ovarian aging in young and middle-aged mice. Reprod Fertil Dev 32: 292-303 2020. https://doi.org/10.1071/rd18472

BÓDIS J, SULYOK E, KOZEGI T, GODONI K, PRÉMUSZ V, VÁRNAGY Á: Serum and follicular fluid levels of sirtuin 1 , sirtuin 6 , and resveratrol in women undergoing in vitro fertilization: an observational, clinical study. J Int Med Res 47: 772-782, 2018. https://doi.org/10.1177/0300060518811228

BORDONE L, MOTTA MC, PICARD F, ROBINSON A, JHALA US, APFELD J, MCDONAGH T, LEMIEUX M, MCBURNEY M, SZILVASI A, EASLON EJ, LIN S-J, GUARENTE L: Sirt1 regulates insulin secretion by repressing UCP2 in pancreatic $\beta$ cells. PLoS Biol 4: e31, 2006. https://doi.org/10.1371/journal.pbio.0040031

COUSSENS M, MARESH JG, YANAGIMASHI R, MAEDA G, ALLSOPP R: Sirt1 deficiency attenuates spermatogenesis and germ cell function. PLoS One 3: e1571, 2008. https://doi.org/10.1371/journal.pone.0001571

FRYE RA: Phylogenetic classification of prokaryotic and eukaryotic Sir2-like proteins. Biochem Biophys Res Commun 273: 793-798, 2000. https://doi.org/10.1006/bbrc.2000.3000

FU M, LIU M, SAUVE AA, JIAO X, ZHANG X: Hormonal control of androgen receptor function through SIRT1. Mol Cell Biol 26: 8122-8135, 2006. https://doi.org/10.1128/mcb.00289-06

HAIGIS MC, GUARENTE LP: Mammalian sirtuins--emerging roles in physiology, aging, and calorie restriction. Genes Dev 20: 2913-2921, 2006. https://doi.org/10.1101/gad.1467506

JIN D, TAN HJ, LEI T, GAN L, CHEN XD, LONG QQ, FENG B, YANG ZQ: Molecular cloning and characterization of porcine sirtuin genes. Comp Biochem Physiol B Biochem Mol Biol 153: 348-358, 2009. https://doi.org/10.1016/j.cbpb.2009.04.004

KOLTHUR-SEETHARAM U, TEERDS K, DE ROOIJ DG, WENDLING O, MCBURNEY M, SASSONE-CORSI P, DAVIDSON I: The histone deacetylase SIRT1 controls male fertility in mice through regulation of hypothalamic-pituitary gonadotropin signaling. Biol Reprod 80: 384-391, 2009. https://doi.org/10.1095/biolreprod.108.070193

LONG GY, YANG JY, XU JJ, NI YH, ZHOU XL, MA JY, FU YC, LUO LL: SIRT1 knock-in mice preserve ovarian reserve resembling caloric restriction. Gene 686: 194-202, 2019. https://doi.org/10.1016/j.gene.2018.10.040

MESZAROSOVA M, SIROTKIN AV, GROSSMANN R, DARLAK K, VALENZUELA F: The effect of obestatin on porcine ovarian granulosa cells. Animal Reprod Sci 108: 196-207, 2008. https://doi.org/10.1016/j.anireprosci.2007.08.011

MORITA Y, WADA-HIRAIKE O, YANO T, SHIRANE A, HIRANO M, HIRAIKE H, KOYAMA S, OISHI H, YOSHINO O, MIYAMOTO Y, SONE K, ODA K, NAKAGAWA S, TSUTSUI K, TAKETANI Y: Resveratrol promotes expression of SIRT1 and StAR in rat ovarian granulosa cells: an implicative role of SIRT1 in the ovary. Reprod Biol Endocrinol 10: 14, 2012. https://doi.org/10.1186/1477-7827-10-14

OSBORN M, ISENBERG S: Immunocytochemistry of frozen and paraffin tissue sections. In: Cell Biology. A Laboratory Handbook, vol. 2. Celis JE (ed.), Academic Press, New York, London, Sydney, Tokyo, Toronto, 1994, pp 361-367. 
PAVLOVA S, KLUCSKA K, VASICEK D, KOTWICA J, SIROTKIN AV: Transcription factor NF-kB (p50/p50, p65/p65) controls porcine ovarian cells functions. Anim Reprod Sci 128: 73-84, 2011. https://doi.org/10.1016/j.anireprosci.2011.09.005

PAVLOVA S, KLUCSKA K, VASICEK D, RYBAN L, SIROTKIN AV: The involvement of SIRT1 and transcription factor NF-kB (p50/p65) in regulation of porcine ovarian cells functions. Animal Reprod Sci 140: 180-188, 2013. https://doi.org/10.1016/j.anireprosci.2013.06.013

RAJENDRASOZHAN S, YANG S-R, KINNULA VL, RAHMAN I: SIRT1, an antiinflammatory and antiaging protein, is decreased in lungs of patients with chronic obstructive pulmonary disease. Am J Respir Crit Care Med 177: 861-870, 2008. https://doi.org/10.1164/rccm.200708-1269oc

RODGERS JT, LERIN C, GERHART-HINES Z, PUIGSERVER P: Metabolic adaptations through the PGC-1 $\alpha$ and SIRT1 pathways. FEBS Lett 582: 46-53, 2008. https://doi.org/10.1016/j.febslet.2007.11.034

SIROTKIN AV: Regulators of Ovarian Functions. Nova Science Publishers, Inc., New York, USA. 2014, 210 p.

SIROTKIN AV, DEKANOVA P, HARRATH AH, ALWASEL SH, VASICEK D: Interrelationships between sirtuin 1 and transcription factors $\mathrm{p} 53$ and NF- $\mathrm{kB}(\mathrm{p} 50 / \mathrm{p} 65)$ in the control of ovarian cell apoptosis and proliferation. Cell Tissue Res 358: 627-632, 2014. https://doi.org/10.1007/s00441-014-1940-7

SIROTKIN AV: The role and application of sirtuins and mTOR signaling in the control of ovarian functions. Cells 5: pii: E42, 2016. https://doi.org/10.3390/cells5040042

SIROTKIN AV, FLORKOVIČOVÁ IK, ŠVARCOVÁ O, RAFAZ J, LAURINČIK J, HARRATH AH: Caloric restriction and IGF-I administration promote rabbit fecundity: Possible interrelationships and mechanisms of action. Theriogenology 90: 252-259, 2017a. https://doi.org/10.1016/j.theriogenology.2016.12.017

SIROTKIN AV, HARRATH AH, GROSSMANN R: Metabolic status and ghrelin regulate plasma levels and release of ovarian hormones in layer chicks. Physiol Res 66: 85-92, 2017b. https://doi.org/10.33549/physiolres.933306

SIROTKIN AV, KADASI A, STOCHMALOVA A, BALAZI A, FOLDESIOVA M, MAKOVICKY P, CHRENEK P, HARRATH AH: Effect of turmeric on the viability, ovarian folliculogenesis, fecundity, ovarian hormones and response to luteinizing hormone of rabbits. Animal 12: 1242-1249, 2018. https://doi.org/10.1017/S175173111700235X.

SIROTKIN A, ALEXA R, KÁDASI A, ADAMCOVÁ E, ALWASEL S, HARRATH AH: Resveratrol directly affects ovarian cell sirtuin, proliferation, apoptosis, hormone release and response to follicle-stimulating hormone (FSH) and insulin-like growth factor I (IGF-I). Reprod Fertil Dev 2019a. https://doi.org/10.1071/rd18425

SIROTKIN AV, ŠTOCHMALOVÁ A, ALEXA R, KÁDASI A, BAUER M, GROSSMANN R, ALREZAKI A, ALWASEL S, HARRATH AH: Quercetin directly inhibits basal ovarian cell functions and their response to the stimulatory action of FSH. Eur J Pharmacol 860: 172560, 2019b. https://doi.org/10.1016/j.ejphar.2019.172560

TATONE C, Di ENIDIO G, VITTI M, DI CARLO M, SANTINI S JR, D'ALESSANDRO AM, FALONE S, AMICARELLI F: Sirtuin functions in female fertility: possible role in oxidative stress and aging. Oxid Med Cell Longev 2015: 659687, 2015. https://doi.org/10.1155/2015/659687

TATONE C, Di EMIDIO G, BARBONETTI A, CARTA G, LUCIANO AM, FALONE S, AMICARELLI F: Sirtuins in gamete biology and reproductive physiology: emerging roles and therapeutic potential in female and male infertility. Hum Reprod Update 24: 267-289, 2018. https://doi.org/10.1093/humupd/dmy003

WOLF G: Calorie restriction increases life span: A molecular mechanism. Nutrition Rev 64: 89-92, 2006. https://doi.org/10.1111/j.1753-4887.2006.tb00192.x 